\title{
Undesirable substances in vegetable oils: anything to declare?
}

\author{
Florence Lacoste \\ ITERG, French Institute for Fats and Oils, Pessac, France
}

Received 8 October 2013 - Accepted 28 November 2013

\begin{abstract}
The presence of undesirable compounds in vegetable and animal oils and fats may have many different origins. Although the potential toxicity of most of these undesirable compounds is real, poisoning risks are rather limited due to the efficient elimination during oil-refining steps, careful conditioning, choice of efficient packaging and industrial quality control management. However the research of contaminants is part of multiple controls conducted by fat and oil industry to verify the conformity of products placed on the market in relation to regulations such as the European commission regulation EC No. 1881/2006 setting maximum levels for some contaminants in food as lead, some mycotoxins, dioxins, polychlorobiphenyls, benzo[a]pyrene. In the absence of regulation, the detection of contaminants must be addressed in partnership with authorities according to the toxicity of molecules. The controls are not confined to environmental contaminants. They also include compounds that can be formed during the production process of vegetable oils such as esters of 3-monochloropropanediol. This article focuses more particularly on heavy metals, polycyclic aromatic hydrocarbons, mineral oils, phthalates and 3-MCPD or glycidyl esters. Aspects such as methods for analysis, limits fixed by EC regulation and occurrence in vegetable oils are discussed.
\end{abstract}

Keywords: Undesirable compounds / toxicity / methods of analysis / limits / occurrence

Résumé - Substances indésirables dans les huiles végétales : rien à déclarer ? La présence de composés indésirables dans les huiles végétales et animales et dans les graisses peut avoir de nombreuses origines différentes. Bien que la toxicité potentielle de la plupart de ces composés indésirables soit réelle, les risques de toxicité s'avèrent néanmoins limités en raison de l'efficacité de leur élimination durant les étapes de raffinage, des précautions apportées au conditionnement, du choix d'un emballage et de la mise en place d'un système d'assurance qualité industriel. Cependant, la recherche de contaminants fait partie des multiples contrôles conduits par l'industrie des huiles et des graisses afin de vérifier la conformité de produits mis sur le marché par rapport aux lois et notamment le règlement de la Commission européenne CE No. 1881/2006 qui fixe les niveaux maximaux de différents contaminants dans l'alimentation comme le plomb, différentes mycotoxines, dioxines, polychlorobiphényles, benzo[a]pyrène. En absence de règlement, la détection de contaminants doit être gérée en partenariat avec des autorités selon la toxicité de molécules. Les contrôles ne sont pas limités aux contaminants environnementaux. Ils incluent aussi les composés qui peuvent être formés pendant le processus de production des huiles végétales comme les esters de 3-monochloropropanediol. Cet article s'intéresse plus particulièrement aux métaux lourds, hydrocarbures aromatiques polycycliques, huiles minérales, phtalates, esters de 3-MCPD et esters de glycidol. Les aspects tels que méthodes d'analyse, limites fixées par la règlementation de la Commission européenne et l'occurrence de cas dans les huiles végétales y sont abordés.

Mots clés : Composés indésirables / toxicité / méthodes d'analyse / limites / occurrence

The presence of undesirable compounds in vegetable oils may have different origins. Environment may induce contamination of crops with metals, dioxins and polychlorobiphenyls from industrial wastes, polycyclic aromatic hydrocarbons or mineral oil from vehicle exhausts; crop protection implements chemicals like insecticides, fungicides or herbicide; mineral oil may also be used to protect grains; production process may lead to the formation of degradation products like polycyclic aromatic hydrocarbons (PAHs) or 3-MCPD esters and glycidol esters; lubricant leak during the process may contaminate

\footnotetext{
^ Correspondence: f.lacoste@iterg.com
}

the oil and contact with plastic material may lead to plasticizer migration such as phthalates.

Transport and storage may also be sources of contamination with mineral oil and chemicals from previous cargoes. Phthalates may also contaminate the oil due to contact with plastic material used during transport and storage.

\section{Heavy metals}

The presence in vegetable oil of heavy metals such as arsenic, lead, cadmium or mercury is mostly due to 
Table 1. Quantification limits of method based on graphite furnace atomic absorption, and regulation limits for oils, concerning cadmium (Cd), lead $(\mathrm{Pb})$, nickel $(\mathrm{Ni})$, arsenic $(\mathrm{As})$ and chromium $(\mathrm{Cr})$.

\begin{tabular}{lccccc}
\hline \multicolumn{1}{c}{ Metals } & $\mathrm{Cd}$ & $\mathrm{Pb}$ & $\mathrm{Ni}$ & $\mathrm{As}$ & $\mathrm{Cr}$ \\
\hline $\begin{array}{l}\text { Lower limit of quantification } \\
\text { (LQ) of atomic absorption }(\mathrm{mg} / \mathrm{kg})\end{array}$ & 0.002 & 0.010 & 0.015 & 0.010 & 0.005 \\
\hline $\begin{array}{l}\text { Regulation limit for oils } \\
(\mathrm{mg} / \mathrm{kg})\end{array}$ & & $\begin{array}{c}0.10 \\
\text { (EU \& Codex) }\end{array}$ & $\begin{array}{c}0.2 \\
\text { (France) }\end{array}$ & $\begin{array}{c}0.10 \\
(\text { Codex })\end{array}$ & \begin{tabular}{c} 
(France) \\
\hline
\end{tabular} \\
\hline
\end{tabular}

environmental contamination. For some of these metals, limit values in vegetable oil have been established by Codex Alimentarius (Codex Alimentarius Standard 193-1995) and the European Commission (EC No. 1881/2006 - contaminants in foodstuffs).

\subsection{Metals: methods and regulations}

Metal content is determined either by graphite furnace atomic absorption or inductively coupled plasma emission, and specific methods are standardized by ISO for copper, iron, nickel, cadmium and lead (Lacoste et al., 1993, 1999). For example, determination of trace amounts of metal in animal and vegetable fats and oils by graphite furnace atomic absorption is specified by ISO 8294 (Cu, Fe, Ni), ISO 15774 (Cd) and ISO $12193(\mathrm{~Pb})$. ISO/TS 21033 standard specifies a method for $\mathrm{Cd}$, $\mathrm{Pb}, \mathrm{Cu}, \mathrm{Fe}$ and Ni determination of trace amounts using inductively coupled plasma optical emission.

The sensitivity of these methods enables to quantify the metals at their regulation limits (Lacoste et al., 2004), such as $0.1 \mathrm{mg} / \mathrm{kg}$ for lead for EC regulation.

\subsection{Metals: occurrence in edible oils and fats}

Oil refining is efficient on metal removal, such as lead that may be present in cold pressed oils. Results from an ITERG study (1992-1999) underlined that all the analysed refined samples do not present any lead, whereas $20 \%$ of the analyzed cold pressed oils may contain lead at a content between 0.02 and $0.1 \mathrm{mg} / \mathrm{kg}$.

\subsection{Heavy metals transfer from soil to rapeseed oil}

A study conducted by Pole d'Aspach, Cetiom and ITERG (ADEME project, 1999-2001) showed that when the crop is cultivated on an cadmium or copper enriched soil, the metal is concentrated mostly in the meal after seed crushing (Fig. 1).

\subsection{Conclusion}

Concerning contamination of oils and fats with heavy metals, regulations and recognized methods do exist, and occurrence of heavy metals in vegetable oils does not represent a real risk.

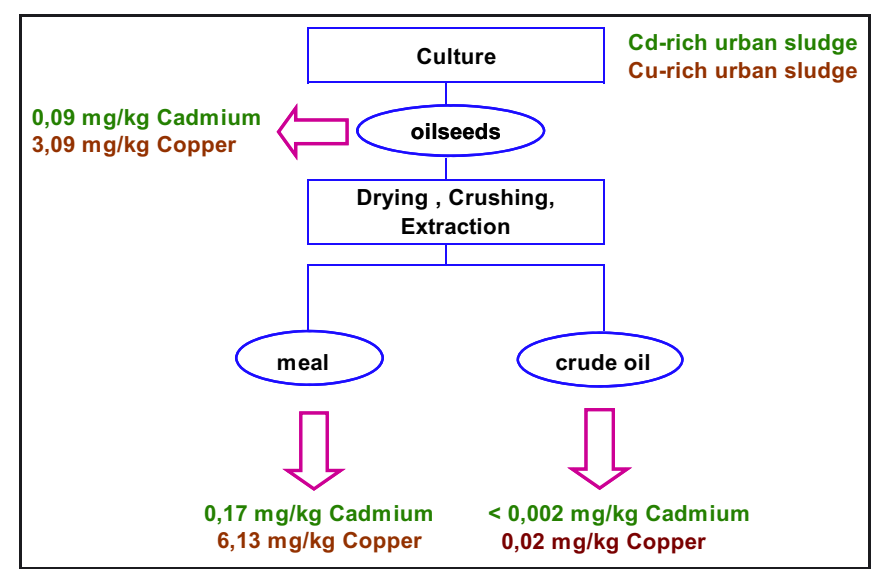

Fig. 1. Heavy metals transfer from soil to rapeseed oil.

\section{Polycyclic aromatic hydrocarbons}

Polycyclic aromatic hydrocarbons (PAHs) are formed by incomplete combustion or pyrolysis of organic material such as wood, petroleum products, coal or food. PAHs have been detected in different types of food particularly grilled meat, cereals, fats and oils. Their presence in vegetable oils may be linked either to environmental contamination or production process. The European commission has fixed a limit for PAHs in vegetable oils.

\subsection{PAHs origins in vegetable oils}

The oils that are the most likely to be contaminated are grapeseed oil, coconut oil, pomace olive oil and sunflower oil to some extent. The common point between these oils is that the raw material is dried before the oil is extracted. When raw material is dried, if it comes into direct contact with combustion smoke, or if temperature is too high, contamination by PAHs is possible.

Then, since PAHs are very lipophilic, they concentrate in the oil during extraction. Crude oil can therefore contain large amount of PAHs.

During the refining process all PAHs should normally be eliminated. Light PAHs are eliminated by the deodorization step, whereas heavy ones are eliminated when treated with activated carbon during the bleaching step.

If previously mentioned steps are not managed correctly, refined oil may contain traces of PAHs. 
Table 2. PAHs regulation: EC No. 1881/2006 Contaminants in foodstuffs.

\begin{tabular}{lccc}
\hline \multicolumn{1}{c}{ PAHs } & $\begin{array}{c}\text { Maximum levels in oils } \\
\text { and fats }(\mu \mathrm{g} / \mathrm{kg})\end{array}$ & $\begin{array}{c}\text { Maximum levels in coconut } \\
\text { oil }(\mu \mathrm{g} / \mathrm{kg})\end{array}$ & $\begin{array}{c}\text { Maximum levels in cocoa } \\
\text { butter }(\mu \mathrm{g} / \mathrm{kg})\end{array}$ \\
\hline $\begin{array}{l}\text { Sum of 4 PAHs: } \\
\text { benzo[a]pyrene } \\
\text { benz[a]anthracene } \\
\text { benzo[b]fluoranthene } \\
\text { chrysene }\end{array}$ & 10.0 & 20.0 & $\begin{array}{c}35.0 \\
\text { from 1.4.2013 until 31.3.2015 }\end{array}$ \\
\hline benzo[a]pyrene & 2.0 & & 30.0 \\
& 2.0 & from 1.4 .2015 \\
\hline
\end{tabular}

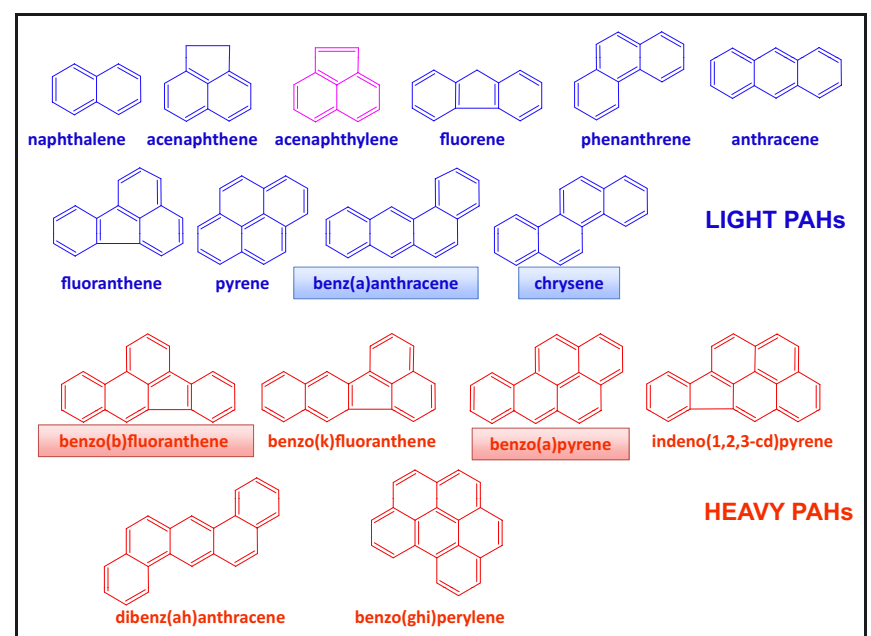

Fig. 2. Structure of PAHs.

\subsection{Structure of PAHs}

Polycyclic aromatic hydrocarbons (PAHs) constitute a large class of organic substances. The chemical structure of PAHs consists of two or more fused aromatic rings. PAHs with less than five aromatic rings are called "light PAHs", PAHs containing five and more rings are called "heavy PAHs" (Fig. 2). Most of the heavy PAHS are genotoxic and 8 HAP have been classified as a carcinogen of category 2 by Commission Directive 2001/59/EC of 6 August 2001: benzo[a]pyrene, benzo[k]fluoranthene, benzo[j]fluoranthene, benz[a]anthracene, benzo[b]fluoranthene, benzo[e]pyrene, chrysene and dibenz[a,h]anthracene.

The 2008 EFSA scientific opinion on PAHs in food concluded that benzo[a]pyrene was not a suitable indicator for the occurrence of PAHs in food and that the sum of four PAHs is a more suitable indicator for the occurrence of PAHs in food: $\mathrm{BaA}$, chrysene, $\mathrm{BaP}, \mathrm{BbF}$.

\subsection{PAHs regulation: EC No. 1881/2006}

Regarding PAH maximum limit, EC regulation was modified recently in order to add to the former $\mathrm{BaP}$ limit that was $2 \mu \mathrm{g} / \mathrm{kg}$, an extra limit for the sum of 4 PAHs which is fixed at $10 \mu \mathrm{g} / \mathrm{kg}$. Coconut oil and cocoa butter have higher maximum limits but some of these values should be reviewed in order to take into account the progress in scientific and technological knowledge.

\subsection{PAHs determination methods}

PAH analysis needs to be performed in two steps in order to isolate and concentrate the analytes before their analysis (Lacoste et al., 2005). Either liquid chromatography LC (alumina, silica gel, C18-silica gel) or high-performance liquid chromatography HPLC (donor-acceptor complex chromatography, size-exclusion chromatography) may be used for PAH isolation, the analysis is then achieved by HPLC with a fluorescence detector or by GC/MS. At the present time, three methods are standardized at the level of ISO for the determination of PAHs in vegetable oils and they are enough sensitive to quantify BaP content:

- ISO 15302 for benzo[a]pyrene in oils (LC + HPLC/FLD)

- ISO 15753 for 12 PAHs in oils (2 SPE + HPLC/FLD)

- and ISO 22959 for 17 PAHs in oils (DACC on-line + HPLC/FLD).

Lower limits of quantification (LQ) for benzo[a]pyrene (BaP) are $0.1 \mu \mathrm{g} / \mathrm{kg}$ with ISO 15302 method, $0.2 \mu \mathrm{g} / \mathrm{kg}$ with ISO 15753 and 0.1 with ISO 22959. These limits fit with the maximum authorized level (from 2.0 to $5.0 \mu \mathrm{g} / \mathrm{kg}$ ).

There is a new project at the level of CEN for the determination of the 4 PAHs in foodstuffs to comply with the new EC regulation.

\subsection{PAHs occurrence in vegetable oils}

A 2004 survey on benzo[a]pyrene from the European Commission (Reports on tasks for scientific cooperation, Report of experts participating in Task 3.2.12, October 2004, "Collection of Occurrence Data On Polycyclic Aromatic Hydrocarbons In Food") confirms that pomace olive oil, grapeseed oil and sunflower oil may present $\mathrm{BaP}$ content higher than $2 \mu \mathrm{g} / \mathrm{kg}$. In this study, more than $60 \%$ of the samples of pomace olive oil had content higher than $2 \mu \mathrm{g} / \mathrm{kg}$ (Fig. 3).

According to ITERG's data, crude sunflower and rapeseed oils could respect the new limits of the EC regulation for $\mathrm{BaP}$ or the sum of the 4 PAHs (Fig. 4).

\subsection{Effect of refining on PAHs}

PAHs removal during refining was studied some years ago for grapeseed oil at ITERG (Lacoste et al., 2003). The results underlined that, when levels of contamination are approximately $600 \mu \mathrm{g} / \mathrm{kg}$ of total PAH, all the heavy PAHs and most 


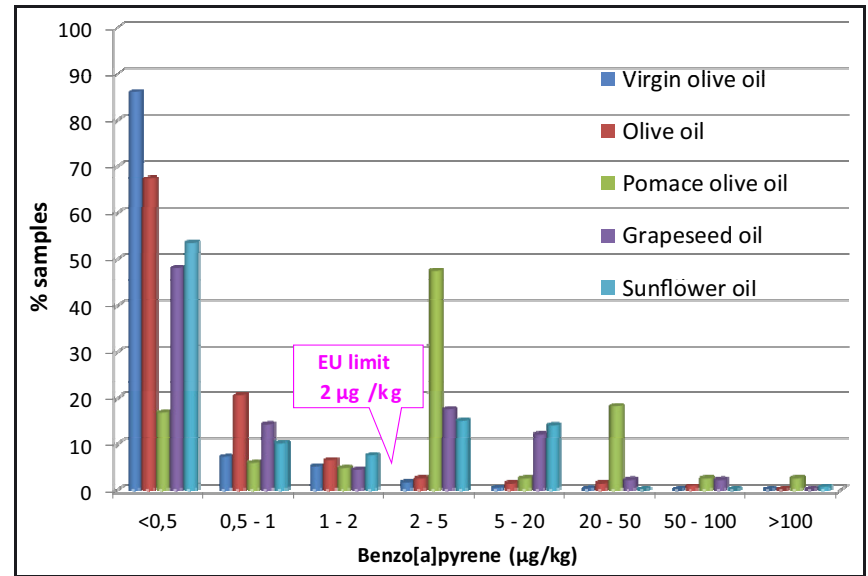

Fig. 3. Occurrence of Benzo[a]pyrène $(\mathrm{BaP})$ in vegetable oil (EU Scoop Task, October 2004).

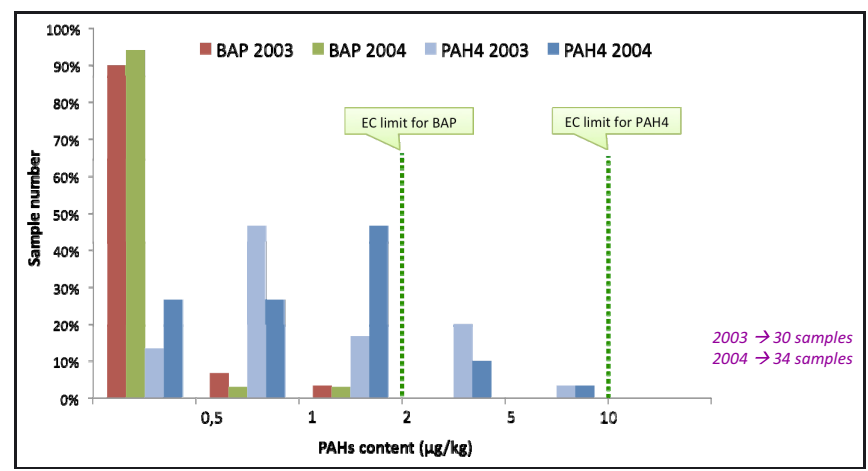

Fig. 4. Polycyclic aromatic hydrocarbons (PAHs) contents in $\mu \mathrm{g} / \mathrm{kg}$ in crude oils (sunflower and rape) (Source: ITERG data, 2003-2004).

of the light PAHs were removed during bleaching step, as active carbon was added to bleaching earths. Remaining light PAHs were eliminated by deodorization step (Fig. 5).

\subsection{Conclusion}

Concerning contamination of oils and fats with PAHs, regulation and recognized methods do exist. However, the occurrence of PAHs in oils may present a risk if the refining steps are not correctly managed.

\section{Mineral oil}

Contamination of vegetable oils with mineral oil may come from environment, crop protection, production process, or transport and storage. The European Commission set a regulation in 2009 ((EC) No. 1151/2009) to limit the mineral content in sunflower oil imported from Ukraine and an EFSA scientific opinion was published in 2012.

\subsection{Mineral oil composition}

Mineral oils are complex mixtures of hydrocarbons varying in carbon number and structure. Mineral oil saturated

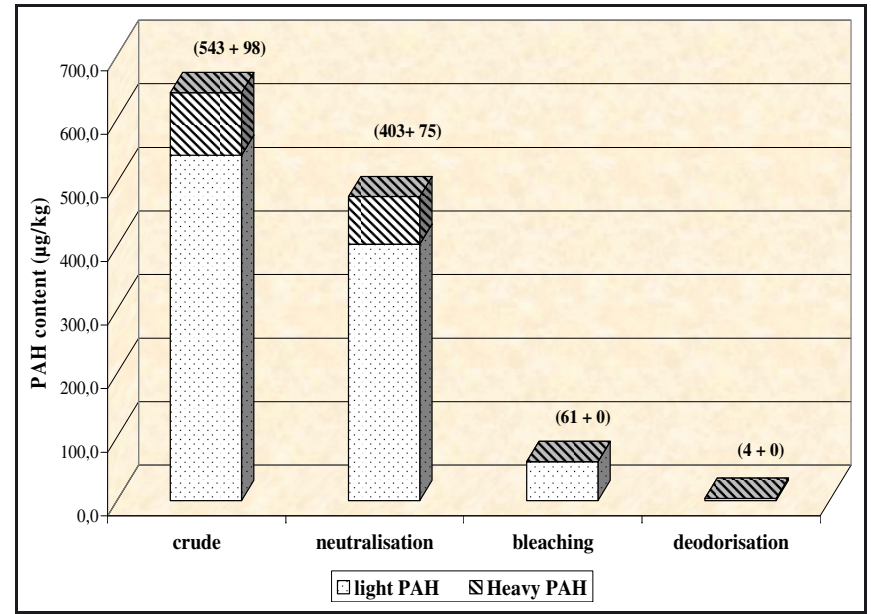

Fig. 5. PAH content (light, heavy and total $\mathrm{PAH}$ ) in grapeseed oil crude, after neutralisation, bleaching and deodorisation (Source: ITERG data, 2000-2001).

hydrocarbons (MOSH) consist of linear and branched alkanes (paraffins), and alkyl-substituted cyclo-alkanes (naphthenes), whilst mineral oil aromatic hydrocarbons (MOAH) include mainly alkyl-substituted polyaromatic hydrocarbons.

Hydrocarbon compound number in mineral oil exceeded 100000 , considering only those with less than 20 carbon atoms! Products, commonly specified according to their physico-chemical properties, may differ in chemical composition depending on the oil source: diesel fuel, white oil, lubricant... Technical grade mineral oil contains 15-35\% MOAH, which is minimized in food grade mineral oil (white oils).

\subsection{EFSA (European Food Safety Authority) scientific opinion, 2012}

Following a request from the European Commission, the EFSA panel on contaminants in the food chain (CONTAM Panel) was asked to deliver a scientific opinion on mineral oil hydrocarbons $(\mathrm{MOH})$ in food. CONTAM Panel concluded:

- that a revision of the existing acceptable daily intakes (ADIs), particularly the temporary group ADI for mediumand low-viscosity mineral oils class II and III is warranted;

- that there is potential concern associated with the current background exposure to MOSH in Europe and in particular in the situation of use of white oils as release agents for bread and rolls and to some extent for spraying of grains;

- that total MOSH and MOAH should be separately determined;

- that among MOSH, there are two sub-classes that should be distinguished based on their molecular mass ranges: MOSH up to $n-C_{16}$ and MOSH from $n-C_{16}$ to $n-C_{35}$ (EFSA, 2012)

\subsection{Mineral oil detected in vegetable oils}

Few publications (Neukom et al., 2002; Reich et al., 1997; Wagner et al., 2001; Moret et al., 2003) dealing with occurrence of oil hydrocarbon reported contents varying from few 
milligrams per kilo to approximately $100 \mathrm{mg} / \mathrm{kg}$ in vegetable oils (Lacoste et al., 2010).

Several recent cases of vegetable oil contamination with mineral oils were reported: in 2008, a contamination of sunflower oil from Ukraine with a mineral oil from unknown origin; in 2009, a contamination of walnut oil with a food grade lubricant oil during refining process; in 2010, identification of compounds eluted as mineral oil in grapeseed oils. In each case the contamination signal was characterized by gas chromatography (GC) as a huge hump of unresolved complex mixture, with some thin peaks of alkanes that are naturally present in the seed.

\subsection{MOSH determination}

Determination of mineral oil saturated hydrocarbons can be achieved in a 2-steps procedure, first a fractionation on silica gel or silica gel impregnated with silver nitrate, then a GC analysis with an internal standard. This method is now evaluated at the level of ISO.

The main critical points of the analysis are the risk of contamination from the lab, the control of solvent evaporation in order to quantify short chain hydrocarbons (quantification of $\mathrm{C} 10$ to $\mathrm{C} 50$ without losing the volatile hydrocarbons), and the lack of precision of the double integration.

A pre-collaborative study was conducted in 2012 (ISO/ WD 17780 pre-collaborative trial) in order to help the participants to gain practical experience and 43 laboratories participated to this trial.

Two samples were analyzed and the dispersion of the results was large even though the information about the contents of mineral oil was given to the participants. As an example, the reproducibility for the spiked olive oil was nearly $50 \mathrm{mg} / \mathrm{kg}$ for a mean value of $60 \mathrm{mg} / \mathrm{kg}$.

The standardization work has to be followed but it will be necessary to improve the harmonization of the laboratory practices.

\subsection{Process effect on hydrocarbons}

A recent study was conducted at ITERG to estimate the base level of mineral oil in vegetable oils. Organic oilseeds and oleaginous fruits were collected; a mechanical crushing at lab-scale was performed, followed by a solvent extraction of the meal. The analysis of the oils showed that the extracted oil was always more concentrated in mineral oil than the pressed oil due to the better extraction power of hexane compared to oil (Tab. 3)

\subsection{Conclusion}

Concerning contamination of oils and fats with mineral oils, new toxicological evaluation is needed before getting an European regulation. Work is still going on in order to get a recognized method. The occurrence of mineral oil in vegetable oils may present a risk for some vegetable oils.
Table 3. Concentration of mineral oil saturated hydrocarbons (MOSH) in the pressed and extracted oil of a collection of organic oilseeds and oleaginous fruits, after mechanical crushing at lab-scale (Komet press), solvent extraction of the meal (Soxhlet) - ITERG data, 2011.

\begin{tabular}{ccc}
\hline Samples & \multicolumn{2}{c}{ MOSH (mg/kg in oil) } \\
\hline & Crushing & Extraction \\
\hline Sunflower & 11 & 53 \\
Rapeseed & 11 & 56 \\
Soya & 5 & 56 \\
Walnut & 6 & 36 \\
Hazelnut & 3 & 21 \\
\hline
\end{tabular}

\begin{tabular}{|l|c|c|}
\hline Di-methyl PHT & DMP & R1=R2=methyl \\
\hline Di-ethyl PHT & DEP & R1=R2=ethyl \\
\hline Di-isobutyl PHT & DIBP & R1=R2=isobutyl \\
\hline Di-butyl PHT & DBP & R1=R2=butyl \\
\hline Di-hexyl PHT & DHexP & R1=R2=hexyl \\
\hline Benzyl butyl PHT & BBP & R1=benzyl R2=butyl \\
\hline Di-n-heptyl PHT & DHepP & R1=R2=heptyl \\
\hline Di-(2-ethyl hexyl) PHT & DEHP & R1=R2=ethyl-2 hexyl \\
\hline Di-n-octyl PHT & DNOP & R1=R2=octyl \\
\hline Di-isononyl PHT & DINP & R1=R2= isononyl \\
\hline Di-isodecyl PHT & DIDP & R1=R2=isodecyl \\
\hline
\end{tabular}

Fig. 6. Chemical structures of phthalates.

\section{Phthalates}

Phthalates are a group of chemicals used to soften and increase the flexibility of plastic and vinyl. As plasticizers are not chemically bound to the polymer, migration of phthalates from plastic materials in significant amounts is possible during production process, transport or storage.

The EFSA Panel on Food Additives, Flavourings, Processing Aids and Materials in Contact with Food (AFC Panel) have undertaken evaluations of the safety of food contact materials (FCM), as well as assessments on other substances used in food in 2012 (EFSA Panel on Food Additives, Flavourings, Processing Aids and Materials in Contact with Food, 2012).

The European Commission has set limits for specific migration for chemicals present in plastic material intended to come into contact with food.

\subsection{Chemical structures of phthalates}

Phthalates are esters of phthalic acids with different alcohols (Fig. 6). The most important congener is di-(2-ethylhexyl)-phtalate (DEHP), which accounts for about $50 \%$ of the world production of phthalates. DEHP is a viscous oily liquid, characterized by a $390.6 \mathrm{~g} / \mathrm{mol}$ molecular weight (MW), a $385{ }^{\circ} \mathrm{C}$ boiling point (BP), a $3 \mu \mathrm{g} / \mathrm{l}$ water solubility, and a high affinity for fat (log Kow: 7.5).

Due to their high affinity for fat, phthalates are soluble in oil and therefore are commonly found in fat-containing foods. 
Table 4. Regulation about use of plastic materials and articles into contact with food, according to (EC) No. 10/2011.

\begin{tabular}{|c|c|c|}
\hline & Specific migration limit in food & To be used as \\
\hline Butyl Benzyl Phthalate (BBP) & $30 \mathrm{mg} / \mathrm{kg}$ & Plasticizer in single-use material \\
\hline Di-isononyl phthalate (DINP) & $\sum=9 \mathrm{mg} / \mathrm{kg}$ & containing non-fatty foods except \\
\hline Di-isodecyl phthalate (DIDP) & & infant formulae. \\
\hline Di(2-ethylhexyl)phthalate (DEHP) & $1.5 \mathrm{mg} / \mathrm{kg}$ & $\begin{array}{l}\text { Plasticizer in repeated use materials } \\
\text { containing non-fatty foods. }\end{array}$ \\
\hline Di-butyl phthalate (DBP) & $0.3 \mathrm{mg} / \mathrm{kg}$ & \\
\hline
\end{tabular}

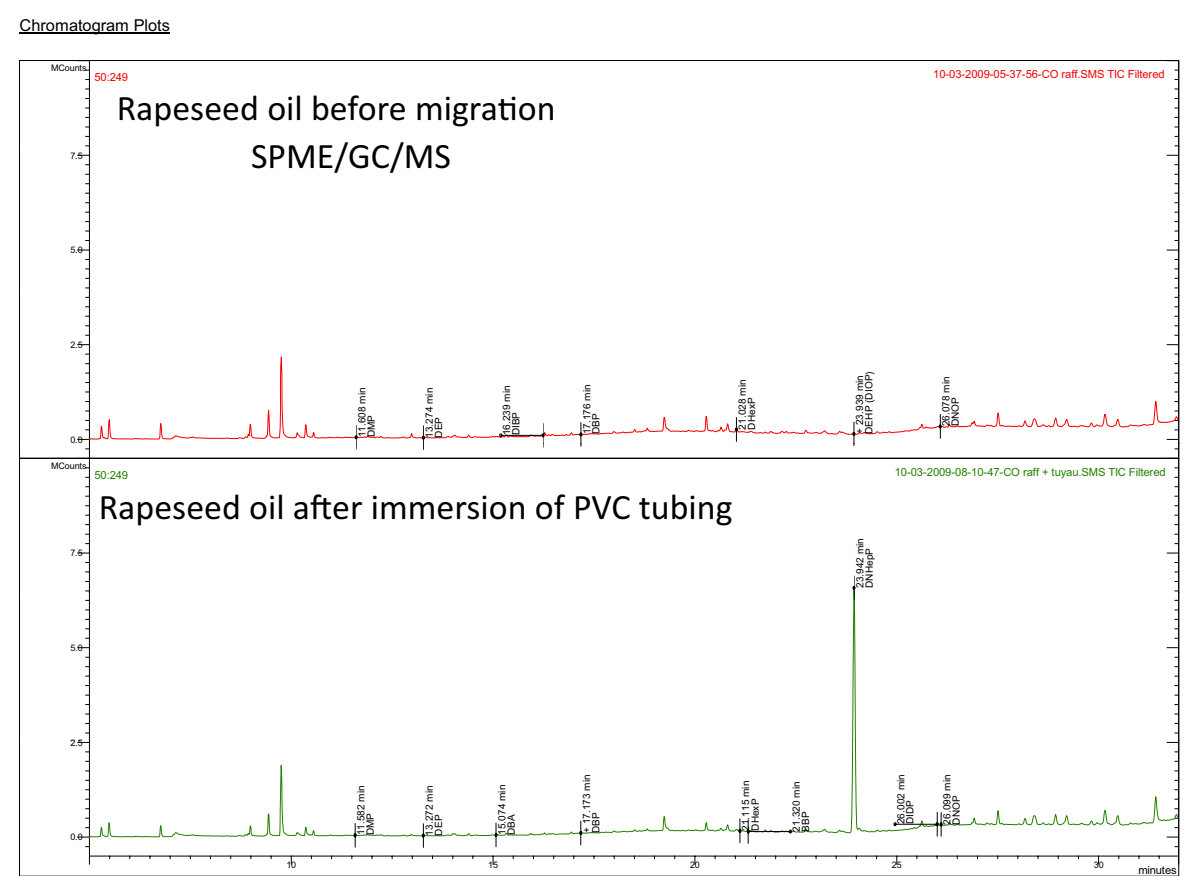

Fig. 7. Analysis for quantifying phthalates, based on solid phase microextraction (SPME) and Gas Chromatography-Mass Spectrometry (GCMS) screening. Detection of di(2-ethylhexyl)phthalate (DEHP) migration in rapeseed oil after immersion of laboratory polychlorovonyle tubing in a rapeseed oil (red: concentration before immersion; green: concentration after immersion) (Source: ITERG data, 2008).

Adverse effects of phthalates on the reproductive system have been reported based on animal studies: phthalates are suspected to be endocrine disruptors.

\subsection{Phthalates occurrence}

Phthalates are used in cosmetics and personal care products (perfume, hair spray, soap, shampoo, nail polish, skin moisturizer) and in a lot of consumer products: flexible plastic, vinyl toys, shower curtains, wallpaper, food packaging, plastic wrap, wood finishes, detergents, adhesives, plastic plumbing pipes, lubricants, medical tubing and fluid bags, insecticides, medical devices, building materials, vinyl flooring, etc.

\section{3 (EC) No. 10/2011 - Plastic materials and articles into contact with food}

EC regulation (Commission Regulation, 2011) sets a limit for specific migration for 5 different phthalates but also specifies the authorized application for the plastic material (Tab. 4).

Phthalates can only be used as plasticizers for plastic material in contact with non-fatty food. So material containing these phthalates cannot be used for oils and fats. Only phthalate free material can be used in the vegetable oil industry.

\subsection{DEHP migration in rapeseed oil}

As an example, after immersion of laboratory polychlorovonyl tubing in rapeseed oil, the presence of Diethylhexylphthalate is detected by gas chromatography-mass spectrometry GC-MS (Fig. 7).

\subsection{Phthalates determination in vegetable oils}

Since 2008, ITERG has been using a direct method of analysis for quantifying phthalates, based on solid phase microextraction (SPME) and GC-MS screening: $1 \mathrm{~g}$ of oil sample is heated at $160{ }^{\circ} \mathrm{C}$ in a $10 \mathrm{ml}$ flask and a fiber coated with PDMS is introduced in the headspace of this flask during $25 \mathrm{~min}$. Compounds adsorbed on the fiber are then volatilised when introducing the fiber in CPG-MS injector. No previous preparation of the samples nor solvent are required. 


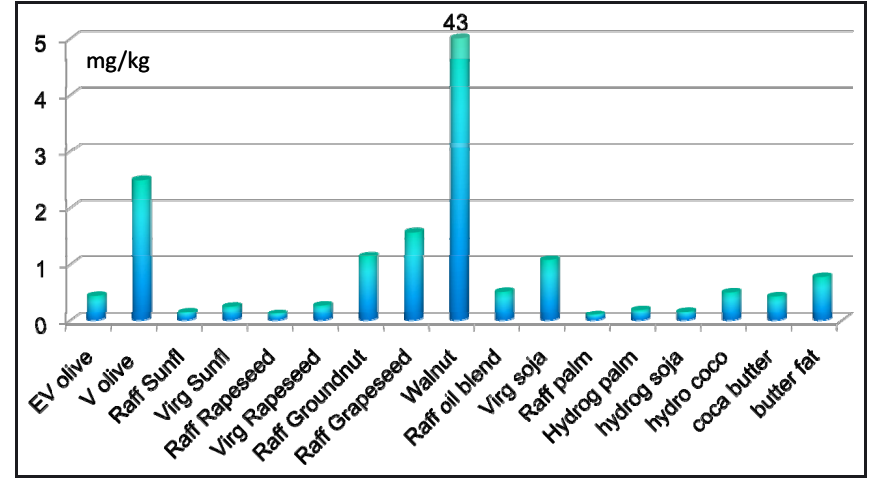

Fig. 8. Evaluation of Diethylhexylphthalate content (in $\mathrm{mg} / \mathrm{kg}$ ) in several vegetable oils and fats (Source: ITERG Data, 2009).

Detection limits of di-butyl-phthalate (DBP), benzyl-butylphthalate (BBP), DEHP and di-(n-octyl)-phthalate (DNOP) are lower than $0.1 \mathrm{mg} / \mathrm{kg}$. Concerning di-(isononyl)-phthalate (DINP) and di-(isodecyl)-phthalate (DIDP), the low chromatographic resolution induces a higher quantification limit.

This rapid (45 min) and sensitive method avoids lab cross contamination. However, the method is not enough sensitive for DINP and DIDP that are blends of congeners.

\subsection{DEHP in oils and fats}

Di(2-ethylhexyl)phthalate was determined in several vegetable oils and fats (ITERG's internal reference). Some samples such as virgin olive oil, refined grapeseed oil, and walnut oil presented DEHP content higher than $1 \mathrm{mg} / \mathrm{kg}$ (Fig. 8).

\subsection{Elimination of phthalates during refining}

The effect of refining on phthalate removal was studied in 2008 by ITERG (Pages et al., 2010).

Chemical refining conducted to variable elimination of $\mathrm{ph}$ thalates: between $19 \%$ and $87 \%$ depending on the molecular weight of the phthalate. At the opposite, physical refining conducted to the total elimination of the three studied phthalates (BBP, DEHP, and DIDP). The low temperature in chemical refining $\left(200{ }^{\circ} \mathrm{C}\right.$ vs. $\left.240{ }^{\circ} \mathrm{C}\right)$ may be the reason of the low efficiency observed for the phthalate with higher molecular weight (DIDP).

\subsection{Conclusion}

Concerning contamination of oils and fats with phthalates, official limit for phthalates in vegetable oils does not exist as plastic material containing phthalates should not be used in the oil industry. There is no recognized methods and cross contamination during the analysis is a real problem. The occurrence of phthalates in vegetable oils may present a risk for some vegetable oils such as walnut oil.

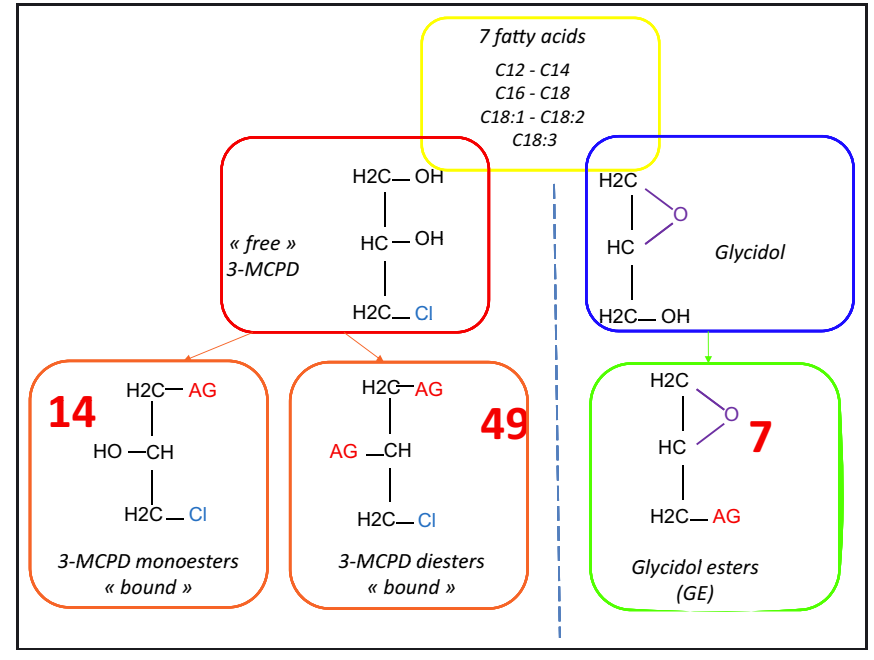

Fig. 9. Structure of 3-MCPD esters and glycidyl esters (Source: Hrncirik, OVID meeting, 2011).

\section{3-MCPD esters and glycidyl esters}

In refined vegetable oils, significant amount of fatty acid esterified 3-MCPD and fatty acid esterified glycidol was reported especially in palm oil. According to the latest scientific knowledge, 3-MCPD esters and glycidyl esters are formed during oil refining especially the deodorization step.

3-monochloropropane-1,2 diol (3-MCPD) is a neoformed compound whose content is regulated by EC in hydrolyzed vegetable proteins and soy sauces: EU regulatory (EC) No. 1881/2006 sets an upper limit of $20 \mu \mathrm{g} / \mathrm{kg}$.

EFSA Scientific Panel on Contaminants in the Food chain (CONTAM) agreed in 2008 on the German Bundesinstitut für Risikobewertung -BfR- assumption (Federal Institute for Risk Assessment, 2009) that 100\% of 3-MCPD is released from its esters in humans (EFSA Panel on Contaminants in the Food Chain, 2008).

\subsection{3-MCPD esters and glycidyl esters: chemical structure}

Taking into account 7 fatty acids that can be esterified either with 3-MCPD or glycidol, 14 monoesters of 3-MCPD can be formed, 49 diesters of 3-MCPD and 7 esters of glycidol, that leads to a theoretical number of 70 esters (Fig. 9).

\subsection{3-MCPD esters and glycidyl esters: analysis strategy}

Two approaches are currently proposed for the determination of 3-MCPD esters and glycidyl esters: direct methods and indirect methods (Tab. 5).

The direct approach proposes the determination of 3-MCPD esters and glycidyl esters without any chemical transformation. These methods allow quantifying individually each ester using sophisticated techniques such as HPLC/MS/MS or HPLC-QTOF/MS. Often a purification step is necessary. However, direct methods need isotopically labelled and unlabelled standards that are not commercially available. 
Table 5. Comparison of direct and indirect method of 3-MCPD esters and glycidol esters analysis.

\begin{tabular}{|c|c|c|}
\hline & Direct methods & Indirect methods \\
\hline \multirow[t]{2}{*}{ Pros } & No chemical reaction & Standards available \\
\hline & Individual quantification of species & Good sensitivity \\
\hline \multirow[t]{2}{*}{ Cons } & Standards not available (60-70 different species) & Reactivity of the analytes (glycidol and 3-MCPD) \\
\hline & $\begin{array}{l}\text { Expensive tools: HPLC/MS/MS or HPLC/TOF/MS } \\
\text { Purification step needed }\end{array}$ & $\begin{array}{l}\text { Global quantification of glycidyl esters and 3-MCPD } \\
\text { esters }\end{array}$ \\
\hline \multirow[t]{7}{*}{ Papers } & Masukawa et al., (2010) & Divinová et al., \\
\hline & Masukawa et al., (2011) & (2004) \\
\hline & AOCS Cd 28-10 (1) & Weißhaar, (2008) \\
\hline & Haines et al., (2011) & DGF C-VI 18 (2010) \\
\hline & Dubois et al., (2011) & Hrncirik et al., (2011) \\
\hline & Dubois et al., (2012) & Kuhlmann, (2011) \\
\hline & Moravcova et al., (2012) & Ermacora et al., (2012) \\
\hline
\end{tabular}

1. The American Oil Chemists' Society (AOCS) and the Japan Oil Chemists' Society (JOCS) released the first validated direct method for glycidyl fatty acid esters in edible oils, AOCS/JOCS Official Method Cd 28-10.

2. Deutsche Gesellschaft für Fettwissenschaft (DGF) evaluated a method for the determination of the sum of ester bound 3-MCPD and Glycidol.

The indirect approach consists in transforming the 3-MCPD esters and of glycidyl esters in 3-MCPD and glycidol and quantifying this two new species by GC/MS. These methods are sensitive but do not provide any structural information on the initial esters. The main drawback of these indirect methods is the reactivity of the new species that can be converted one into the other.

Theses two complementary approaches had led to numerous publications.

ITERG currently performs both the analysis of glycidyl esters using AOCS Cd 28-10 method, or the analysis of 3-MCPD esters and glycidyl esters by Dr Kuhlmann's method.

\subsection{3-MCPD esters determination: SGS indirect method (assay A)}

During essay A, 3-MCPD esters are hydrolyzed with sodium hydroxide in presence of methanol during $12 \mathrm{~h}$ at $-26{ }^{\circ} \mathrm{C}$, using an internal standard (deuterated 3-MCPD dipalmitate). Three new species are formed: 3-MCPD, 3-MCPD-d5 and glycidol. When adding sodium bromide, glycidol is transformed in 3-monobromopropanediol. However, some 3-MBPD-d5 appears during the reaction, proving that 3-MCPD can be converted into glycidol.

Assay B is dedicated to glycidyl ester determination, using an isotopically labelled glycidyl ester. However, glycidol may be overestimated if conversion of 3-MCPD into glycidol is too important. As an example this conversion rate can reach $10 \%$ if the mixture stays at room temperature for more than $3 \mathrm{~min}$.

\subsection{Glycidyl ester determination according to joint AOCS/JOCS Cd 28-10}

Glycidyl esters can be individually determined with AOCS/JOCS direct method. The oil sample is purified on two different solid phase extraction cartridges, and the extract is then analyzed by HPLC/MS with atmospheric-pressure chemical ionization interface. External calibration with five glycidyl esters is used. Recovery test is correct and reproducibility results acceptable.

\subsection{Occurrence of 3-MCPD in edible oils}

3-MCPD contents higher than $2 \mathrm{mg} / \mathrm{kg}$ are observed for palm oil, walnut oil and grapeseed oils. The presence of diacylglycerols (DAG) is usually associated with 3-MCPD because they have been identified as the potential precursors. In our analyses (ITERG's internal reference), there was no correlation between DAG and 3-MCPD. Lack of information concerning ion chloride ion content may explain these results.

\subsection{Conclusion}

Concerning contamination of oils and fats with 3-MCPD esters and glycidyl esters, the European Commission does not have enough information about the real toxicity of the 3-MCPD esters and the glycidyl esters to set a limit for vegetable oils. A recognized method does exist for the determination of glycidyl esters but not for 3-MCPD esters. The occurrence of 3-MCPD esters and glycidyl esters does present a risk for some vegetable oils such as palm oil.

\section{General conclusions}

Research of contaminants is part of multiple controls conducted by fat and oil industry to fulfil the EC regulation No. 1881/2006.

In the absence of regulation, the detection of contaminants must be addressed in partnership with authorities according to the toxicity of molecules.

Risks are rather limited due to the efficient elimination during oil-refining steps. 
However some contaminants can be formed during the production process of vegetable oils such as esters of 3-MCPD and esters of glycidol.

\section{References}

Divinová V, Svejkovská B, Doležal M, Velíšek J. 2004. Determination of free and bound 3-chloropropane-1,2-diol by gas chromatography with mass spectrometric detection using deuterated 3-chloropropane-1,2-diol as internal standard. Czech J. Food Sci. 22: 182-189.

Dubois M, Tarres A, Goldmann T, Loeffelmann G, Donaubauer A, Seefelder W. 2011. Determination of seven glycidyl esters in edible oils by gel permeation chromatography extraction and liquid chromatography coupled to mass spectrometry detection. $J$. Agric. Food Chem. 59: 12291-12301

Dubois M, Tarres A, Goldmann T, Empl AM, Donaubauer A, Seefelder W. 2012. Comparison of indirect and direct quantification of esters of monochloropropanediol in vegetable oil. $J$. Chromatogr. A 1236: 189-201.

EFSA Panel on Contaminants in the Food Chain (CONTAM). Statement of the Scientific Panel on Contaminants in the Food chain (CONTAM) on a request from the European Commission related to 3-MCPD esters. Adopted: 28 March 2008 Published: 31 March 2008.

EFSA Panel on Contaminants in the Food Chain (CONTAM). 2012. Scientific opinion on mineral oil hydrocarbons in food. EFSA Journal 10: 2704, 185 p.

EFSA Panel on Food Additives, Flavourings, Processing Aids and Materials in Contact with Food (AFC Panel). 2012. Food contact materials, flavouring substances and smoke flavourings. EFSA Journal 10: s1007. Available at: http://www.efsa.europa.eu/fr/ efsajournal/doc/as1007.pdf

Ermacora A, Hrncirik K. 2013. A Novel method for simultaneous monitoring of 2-MCPD, 3-MCPD and glycidyl esters in oils and fats. J. Am. Oil Chem. Soc. 90: 1-8.

European Commission regulation. 2011. Regulation No. 10/2011 of 14 January 2011 on plastic materials and articles intended to come into contact with food. Official Journal of the European Union L12: 1-89.

Federal Institute for Risk Assessment (BfR). 2009. Initial evaluation of the assessment of levels of glycidol fatty acid esters detected in refined vegetable fats (in German). Available at: http:// www.bfr.bund.de/cm/208/erste_einschaetzung_von_glycidol_ fettsaeureestern.pdf. BfR Opinion No. 007/2009, 10 March.

Haines T, Adlaf K, Pierceall R, Lee I, Venkitasubramanian P, Collison M. 2011. Direct determination of MCPD fatty acid esters and glycidyl fatty acid esters in vegetable oils by LC-TOFMS. J. Am. Oil Chem. Soc. 88: 1-14.

Hrncirik K, Zelinkova Z, Ermacora A. 2011. Critical factors of indirect determination of 3-chloropropane-1,2-diol esters. Eur. J. Lipid Sci. Technol. 113: 361-367.
Kuhlmann J. 2011. Determination of bound 2,3-epoxy-1-propanol (glycidol) and bound monochloropropanediol (MCPD) in refined oils. Eur. J. Lipid Sci. Technol. 113: 335-344.

Lacoste F, Castera A, Lespagne J. 1993. Dosage des métaux toxiques dans les corps gras: cadmium, plomb, étain, arsenic et chrome (méthodes et applications). Rev. Fr. Corps Gras 40: 19-31.

Lacoste F, Van Dalen G, Dysseler P. 1999. The determination of cadmium in oils and fats by direct graphite furnace atomic absorption spectrometry. Pure Appl. Chem. 71: 361-368.

Lacoste F, Raoux R. 2003. Undesirable compounds in oils and fats: analysis and regulation, $O C L$ 10: 93-98.

Lacoste F, Raoux R, Dubois D, Soulet B. 2003. Problématiques des hydrocarbures aromatiques polycycliques dans les corps gras. OCL 10: 287-95.

Lacoste F, Soulet B, Arnaud JN, Brenne E, Lechat H. 2004. Contrôle de la sécurité sanitaire de l'huile d'olive vierge. OCL 11: 210 216.

Lacoste F, Lechat H, Pagès X, Arnaud JN, Brenne E, Soulet B, Camisuli B, Birot C, Fazeuilh S, Escabasse J. 2005. Contrôle des composés indésirables dans les huiles végétales et mise en place d'observatoires. OCL 12: 372-377.

Lacoste F, Joffre F, Coustille JL, Morin O, Soulet B, Brenne E, Griffon H. 2010. Détection de contaminants dans les huiles végétales : bilan à fin 2009. OCL 17: 75-80.

Masukawa Y, Shiro H, Nakamura S, Kondo N, Jin N, Suzuki N, Ooi N, Kudo N. 2010. A new analytical method for the quantification of glycidol fatty acid esters in edible oils. J. Oleo. Sci. 59: 81-88.

Masukawa Y, Shiro H, Kondo N, Kudo N. 2011. Generalized method to quantify glycidol fatty acid esters in edible oils. J. Am. Oil Chem. Soc. 88: 15-21.

Moravcova E, Vaclavik L, Lacina O, Hrbek V, Riddellova K, Hajslova J. 2012. Novel approaches to analysis of 3-chloropropane-1,2diol esters in vegetable oils. Anal. Bioanal. Chem. 402: 28712883

Moret S, Populin T, Conte LS, Grob K, Neukom HP. 2003. Occurrence of C16-C45 mineral paraffins in olives and olive oils. Food Addit. Contam. 20: 417-426.

Neukom HP, Grob K, Biedermann M, Noti A. 2002. Food contamination by $\mathrm{C} 20-\mathrm{C} 50$ mineral paraffins from the atmosphere. Atmos. Environ. 36: 4839-4847.

Pages X, Morin O, Birot C, Gaud M, Fazeuilh S, Gouband M. 2010. Raffinage des huiles et des corps gras et élimination des contaminants. OCL 17: 86-99

Reich AG, et al. 1997. Intake of naturally occurring alkanes. Prepared for the American Petroleum Institute by TAS-ENVIRON. Available at: http://www.inchem.org/documents/jecfa/jecmono/ v50je04.htm.

Wagner C, Neukom HP, Grob K, Moret S, Populin T, Conte LS. 2001. Mineral paraffins in vegetable oils and refinery by-products for animal feeds. Mitt Lebensmittelunters Hyg. 92: 499-514.

Weißhaar R. 2008. Determination of total 3-chloropropane-1,2-diol (3-MCPD) in edible oils by cleavage of MCPD esters with sodium methoxide. Eur. J. Lipid. Sci. Technol. 110: 183-186.

Cite this article as: Florence Lacoste. Undesirable substances in vegetable oils: anything to declare? OCL 2014, 21(1) A103. 